\title{
A Comprehensive Survey on Computer Engineering ESP Course in Current Situation of Iranian Universities
}

\author{
Mohammad Amin Manoochehri, MA \\ Department of Foreign Languages and Linguistics, Fars Science and Research branch \\ Islamic Azad University, Marvdasht, Iran \\ Department of Foreign Languages and Linguistics, Marvdasht branch \\ Islamic Azad University, Marvdasht, Iran \\ E-mail: Mtalaaee917@gmail.com
}

Azadeh Nemati, Phd (Correspondin author)

Department of English Language Teaching, Jahrom Branch

Islamic Azad University, Jahrom, Iran

E-mail: azadehnematiar@yahoo.com

Received: March 13, 2015 Accepted: May 10, 2015 Published: November 13, 2015

doi:10.5296/ijele.v4i1.8572 URL: http://dx.doi.org/10.5296/ijele.v4i1.8572

\begin{abstract}
A successful educational system evaluates existing programs with regard to objectives, instructional procedures, achievements and tries to revise them and develop innovative ones. English for Specific Purposes (ESP) has been planned as a compulsory course for students of all fields of study (except English) in Iranian universities. This survey was conducted to investigate an ESP course in the field of computer engineering in the current situation of Iranian universities by examining instructors' attitudes. The participants were 30 university instructors from thirteen universities of Iran. To collect the data, a researcher-made questionnaire consisting of both quantitative and qualitative items was used as well as one-sample t-test was employed to analyze the data. The results indicated that ESP instructors' attitudes toward their ESP course were below the expected value. The findings revealed that the current situation of ESP courses in Iran was actually problematic and needed to be rectified. The findings of this study were supported by the research conducted by Mirza Suzani, Yarmohammadi and Yamini, (2011). Different groups could use the findings of this study including course developers, program organizers, policymakers, students and instructors.
\end{abstract}

Keywords: ESP, computer engineering, university instructors, attitude 


\section{Introduction}

According to Johns, cited in Celce-Murcia (2006, p.43) English for Specific Purposes (ESP) is a movement based on the proposition that all language teaching should be tailored to the specific learning and language use needs of identified groups of students and also sensitive to the social culture context in which these students will be using English. ESP can be classified into two sections: English for academic purposes (EAP) and English for occupational purposes (EOP). EAP serves in academic and EOP in occupational settings (Dudley-Evans and St. John, 1998, p.6).

From the 1980s, ESP has grown to become one of the most important of EFL instructions. The main purpose of ESP was to train students to master their own field of study in English for their occupation positions in the future. An ESP program was therefore made on an assessment for purposes and needs and the function for which English is required (Jordan, 1997).

Indeed, the recent developments in all fields of basic sciences, politics, economics, and culture strongly highlight the usefulness of ESP which is significantly being increased in today's world. The fundamental point is that English is not taught as a subject specified from students' real world. Instead it is integrated into a subject-matter area necessary to the field of learner. In other words, we cannot refuse the statement that ESP teaching should focus on procedures suitable for learners whose main ends for the future is to learn English for specific purpose other than learn the language system itself.

ESP has been devised as a compulsory course for students of all fields of sciences in Iranian universities. This course is offered for those who are going to become qualified as professional experts in their field of study. In addition, the recommendation on employment of the qualified graduates who master their field of study in English as an international language is being strongly emphasized in Iran. According to Purpura and King (2003) ongoing changes and increasing globalization have increased the importance of communication in English at the workplace both within and across boundaries. Unfortunately not much research has been conducted on ESP in area of language teaching in Iran or other countries and the importance and real meaning of ESP are seldom emphasized in academic and research institutions. Mirza suzani, Yarmohmmadi and Yamini (2011) believe that the logic behind ESP is still unknown to most students.

The Iranian academic society seems to undergo an ill-judged policy toward ESP because there is no empirical evidence of its impact on the learners' future job and requirements. When graduates ask for a job, they notice that they are asked about their English proficiency in their field of study and then they will be confident that their English knowledge level is not sufficient to fulfill their job purposes. Mazdayasna and Tahririan, 2008; Atai and Tahririan, 2003; Eslami, 2010 believed that after completing their degree programs, the majority of graduates lack the foreign language proficiency they are expected to demonstrate.

We now agree that above statements can direct us to needs analysis which is highly recommended by pedagogical theoreticians. Therefore, it is the needs analysis which can 
increase ESP quality. For example, it might develop the reading skills for those who want to be business administrators or it might assist the development of spoken skills in students who want to be news correspondents. Based on what Hyland (2006) believed needs analysis, as an indispensable part of ESP courses, is defined as systematic way of seeking students' language need. So ESP instructors should consider all principles of teaching ESP courses in order to bridge the gap between theory and practice.

\subsection{Statement of the Problem}

It seems that the Iranian academic society has failed to meet the goals behind ESP since most graduates in the field of computer engineering lack sufficient familiarity with English language needed for their career. They complain to have not enough capabilities in this area. On the other hand, they criticized that they have not learned many practical expressions related to their field of study or have forgotten those few useful expressions in their ESP textbooks. It seems that the computer engineering ESP program in Iranian universities has not been performed successfully. Therefore, there is a need to pay much more attention to this area of language and help to improve the level of students' knowledge for their future ends.

\subsection{Significance of the Study}

The significance of this study is: first, to inform the current weaknesses, challenges and hindrances of ESP course in the field of computer engineering in universities from the perspective of instructors; secondly, to offer some effective guidelines, suggestions for improvement of existing ESP program in Iran based on suggestions and criticisms of ESP instructors given to the researchers; thirdly, the instructors, students, researchers, program organizers, evaluators, administrators, course designers and ...etc can benefit from the final findings of current research.

Furthermore, the distinguishing feature of this study is that it is the first one, to date, for which the data were collected from ESP instructors in thirteen Iranian universities. Therefore, instructors, students, researchers, program organizers, evaluators, administrators, course designers and ...etc. can benefit from the final findings of this study. The findings of this research will hopefully open a new route in increasing the efficiency of ESP programs in Iran.

\subsection{Research Question}

This research intends to answer the following question:

1_ What is the attitude of instructors toward ESP program for the computer engineering major?

\section{Literature Review}

According to Hutchinson and Waters (1987) when the Second World War ended, new scientific, technical and economic demands grew and English became the international language. Therefore, the English language was determined to be taught in a way that serves different purposes. Furthermore, some changes took place in linguistics, which demanded focus on communicative aspects of language and learners' needs in specific contexts. 


\section{Macrothink}

International Journal of English Language Education

ISSN 2325-0887

2016, Vol. 4, No. 1

English for Specific Purposes (ESP) or English for Special Purposes was coined as a term in the1960's as it became increasingly clear that general English courses frequently did not meet learners' or employers' needs. When English was known as an international language in the world and technology, medicine, education, and research were growing, the demand for ESP grew rapidly, particularly in EFL countries where English is mainly used for instrumental goals. People in these countries learn English in order to accomplish the school curriculum requirement, to pass standardized English proficiency tests, or to achieve promotion or professional development at work. Instead of learning English for such purposes, it is better to learn English as it relates to their professional fields so that they can easily find a job and be more professional.

ESP has some characteristics. That is, Absolute and variable. There are two definitions on basis of Strevens' (1988) and Dudley-Evans and St. John (1998). Strevens' (1988) definition makes a distinction between four absolute and two variable characteristics:

\section{Absolute Characteristics:}

ESP consists of English language teaching which is:

$\rightarrow$ Designed to meet specified needs of the learner;

$\rightarrow$ Related in content (i.e. in its themes and topics) to particular disciplines, occupations and activities;

$\rightarrow$ Centered on the language appropriate to those activities in syntax, lexis, discourse, semantics, etc., and analysis of this discourse;

$\rightarrow$ In contrast with General English.

II. Variable characteristics:

ESP may be, but is not necessarily:

$\rightarrow$ Restricted as to the language skills to be learned (e.g. reading only);

- Taught according to any pre-ordained methodology (Gatehouse, 2001 cf. Strevens, 1998, pp. 1-2).

This definition tries to identify ESP in contrast with General English. Therefore, the emphasis is on "Specific English" that belongs to some particular discipline, occupation or activity. This definition makes it mandatory that ESP courses should concentrate on the language, i.e. syntax, lexis, discourse, semantics etc., which is appropriate for some particular discipline, occupation or activity. Dudley-Evans and St. John (1998, p. 4-5) have presented a modified definition of ESP which is also comprised of absolute and variable characteristics of ESP that are as follow:

\section{Absolute Characteristics}

- ESP is defined to meet specific needs of the learner;

$\rightarrow$ ESP makes use of the underlying methodology and activities of the discipline it serves; 


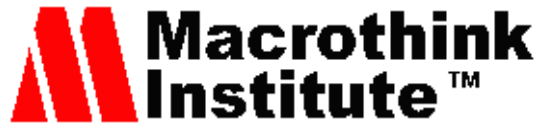

- ESP is centered on the language (grammar, lexis, register), skills, discourse and genres appropriate to these activities.

II. Variable Characteristics

$\rightarrow$ ESP may be related to or designed for specific disciplines;

$\rightarrow$ ESP may use, in specific teaching situations, a different methodology from that of general English;

$\rightarrow$ ESP is likely to be designed for adult learners, either at a tertiary level institution or in a professional work situation. It could, however, be for learners at secondary school level;

$\rightarrow$ ESP is generally designed for intermediate or advanced students;

$\rightarrow$ Most ESP courses assume some basic knowledge of the language system, but it can be used with beginners".

Therefore, ESP instructors should obtain special training in order to teach such courses effectively because they are not only teaching English but also particular subject- matters. More and more universities all over the world are offering ESP courses to meet the global needs as well as to meet students' future career needs. The demand for ESP has drawn some authorities and administrators' attention in many countries to claim that ESP should replace English for General Purposes (EGP), the long-existing practice of English language teaching in many universities, and thus become the mainstream of college English education. Therefore, EGP is basic language learning to be studied before, but not during college; College English should be more advanced, more specialized, and match students' majors of study, particularly in technological universities where students are trained to perform on-the-job; and finally, compared with EGP, ESP is much more effective in increasing students' learning motivation because it relates to their fields of study and meets their needs.

As most researchers agree that instructors nowadays, however, are much more aware of the importance of needs analysis, and published textbooks have given instructors a variety of choices to select materials which can closely meet the goals of ESP learners. Perhaps this demonstrates the influence that the ESP approach has had on English teaching in general. Nevertheless, the route between two branches of English where ESP courses should be substituted for EGP ones has not been elucidated yet. Although many 'General English' instructors can be described as using an ESP approach, basing their syllabi on a learner needs analysis and their own specialist knowledge of using English for real communication, many so-called ESP instructors are employing an approach furthest from that described above. Thus, it can be said that ESP derives from the need to use language as a tool in facilitating success in professional life.

\subsection{Previous Studies on ESP in Iran}

As Kiany (2005) mentioned, the First National ESP/EAP Conference in Iran was held in 2005, and 46 papers and 11 sample lessons were presented at the conference. Some of these studies are: 


\section{Macrothink}

Farhady (2005) discussed ESP parameters, namely needs, materials, method, learner, teacher, and context. He began with a brief history of materials development sponsored by SAMT and concluded by a series of suggestions to improve ESP in Iran such as carrying out thorough needs analyses, changing the designs and concepts of the materials, training qualified teachers, and reforming the testing procedures and Nikpour (2009) referred to some points of ESP textbook, materials and needs analysis of nursing students of Fatemeh Zahra College Shiraz-Iran. She had done this by using questionnaires and interviews.

A second point, Soleimani (2005) referred to some weak points of ESP books published by SAMT, and has some comments on recent improvements. However, the paper fell short of practical suggestions, which would be welcomed and appreciated. In addition, Suzani (2005) turned the spotlight on the weak points of ESP courses and materials for a specific group of students. He then offered general suggestions to come up with more productive ESP classes for the students. Moreover, Shokouhi (2005) criticized traditional approaches to ESP materials development. He mainly favored a rhetorical framework, covering discoursal aspects of texts. The framework consisted of certain strategies and techniques for skimming and scanning information based on a procedural reading model. Another study also conducted by Khani and Tahririan (2005) reviewed traditional, chair-driven approaches to taxonomizing ESP and push a new, research-based one. To take more account of the dynamic nature of learning, they criticized those taxonomies on both philosophical and empirical grounds, and try to replace the notion of task with task-technique, and that of cognitive style with learner variables.

Mozayan (2005) talked about the improvement of reading comprehension ability of Iranian Medical students. He emphasized the use of diagrams to reinforce text comprehension. Mozayan lent empirical support to his argument through a pilot study. He also presented a proposal including a complete lesson, interpolated with instructions and explanations for each particular section and Farnia (2005) showed that ESP vocabulary learning on the Internet is more effective than that by the traditional text-based approach. She had done this by means of a pilot study. Above all, Ajideh (2005) focused on the learner-centered approach. He argued for learner autonomy, goal-orientedness, process-orientedness, and metacognition, and touches upon TEFL in Iran to see how much it related to these factors.

\section{Methodology}

\subsection{Participants}

The participants were ESP instructors of universities. Since this research was going to be conducted comprehensively, ESP instructors of many Iranian universities were invited to cooperate. Thirty instructors of universities from thirteen universities of Iran participated in this study. Their cooperation actually deserved to be strongly appreciated. In order to show the number of all of the participants with their specifications in brief, it was necessary to draw a Table which informs exactly the necessary variables. Table1 shows the demographic information of the participants. 
Table 1. characteristics of the Participants

\begin{tabular}{ll|l|l|l}
\multicolumn{2}{l|}{ PARTICIPANTS } & \multicolumn{2}{l}{$\begin{array}{l}\text { INSTRUCTORS } \\
\text { DEGREE }\end{array}$} \\
\cline { 2 - 4 } & $\begin{array}{l}\text { ESP } \\
\text { INSTRUCTORS }\end{array}$ & AGE & MASTER & PHD \\
Male & 21 & $30 \_55$ & 16 & 5 \\
Female & 9 & $28 \_45$ & 4 & 5 \\
\end{tabular}

\subsection{Instrumentation}

The instrument used in this study was a new questionnaire made by the present researchers to ascertain the attitudes of instructors toward the computer engineering ESP course. The reliability was examined by Factor analysis Cronbach' alpha (It was found to be 0.756) and the validity was carried out through using experts' judgments and interview. It was consisted of two main parts: quantitative and qualitative sections. The quantitative component was designed to obtain some information about the present status of course book and teaching materials, the method of teaching and testing, the availability of audio-visual aids and the ESP classroom quality. Furthermore, it was made up of twenty five items in the form of Likert Scale. A commonly used five-point Likert scale format encompasses: 1. Strongly agree, 2- Agree 3- Neither agree nor disagree (No idea), 4- Disagree, 5- strongly disagree.

In the second section, four open-ended items were included. As Dornyei (2007) believed that "by permitting greater freedom of expression open-ended items can provide a far greater richness than fully quantitative items". The purpose was to achieve a fuller understanding of the target phenomenon. It was intended to enquire the participant preferences about university instructors' expertise (English or non-English) for teaching ESP courses, strengths and weaknesses of their ESP class and their suggestions for improvement of this course. The validity and reliability of the questionnaire will be discussed in the following sections.

\subsection{Procedure}

The data were collected by distributing a Persian questionnaire to intended respondents to give their perspectives. Then thirty ESP university instructors' attitudes were examined using the Likert Scale. The participants read each statement in the scale and decided to select any of the following responses 'strongly agree' 'agree' 'neutral' 'disagree' 'strongly disagree' with the statements. Each response had its value ranging from 1 to 5 . The measure yielded a global score ranging from 25 to 125 .

\subsection{The Validity and Reliability of Questionnaire}

\subsubsection{The Validity of the Questionnaire}

Expert judgments were used to ensure the content validity of the questionnaire. To this end, it 
was given to three experts to examine it and find out the problems. Through judgment, some items were completely omitted and some of them were reworded. Afterward, the committee members' advice was sought. Each strongly confirmed the appropriateness of the questionnaire with regard to subject matter content and the objectives of the research.

\subsubsection{The Reliability of the Questionnaire}

The procedure used to administer the questionnaire began with checking its reliability.

Table 2. Distribution of Gender

\begin{tabular}{||l|l|l|}
\hline Participants & No. of Items & Cronbach's Alpha \\
\hline 30 & 25 & 0.756 \\
\hline
\end{tabular}

The reliability was tested by the Cronbach's alpha for 30 instructors. It was found to be 0.756 which is an acceptable value. Thus, the questionnaire was reliable.

\subsection{Data Analysis}

The data were analyzed through SPSS software version 21 to obtain descriptive and inferential statistics. To this end, one-sample t-test for ESP instructors' attitude toward their ESP course was used. Furthermore, the instructors' responses to four open-ended questions were taken into consideration in order to give more detailed discussion and conclusion. The descriptive and inferential statistics and analytical responses have been presented in the following section.

\section{Statistical Results}

Table 3. Statistics for ESP instructors' attitudes toward ESP course

\begin{tabular}{|l|l|l|l|l|l|l|l|}
\hline Group & $\mathrm{N}$ & Mean & $\begin{array}{l}\text { Std. } \\
\text { Deviation }\end{array}$ & Kurtosis & Skewness & Minimum & Maximum \\
\hline Instructor & 30 & 63.10 & 9.876 & -0.034 & -0.155 & 40 & 81 \\
\hline Total & 30 & 63.10 & 9.876 & -0.034 & 0.155 & 40 & 81 \\
\hline
\end{tabular}

Table 3 showed statistics for the attitude toward ESP course in ESP instructors. It indicated that the attitude mean was 63.10 with a standard deviation of 9.876 , ranged between 40 and 81. The Skewness and Kurtosis were in the accepted range (between -1 and 1), so the distribution was near to the normal. 


\section{Macrothink

Table 4. Kolmogorov-Smirnov test of normality for attitude

\begin{tabular}{||l|l|l||}
\hline Group & $\mathrm{Z}$ & Sig. (p) \\
\hline instructor & 0.841 & 0.479 \\
\hline
\end{tabular}

The above Table shows results for the Kolmogorov-Smirnov Test. Since the p-values were greater than 0.05 ( $p>0.05$ ) for ESP instructors, the statistics were not significant which means that the distributions were normal. Thus, parametric tests could be used.

\section{Research Question: What is the attitude of instructors toward ESP course for the computer engineering major?}

Since scores were between 25 and 125 (25 questions each scored between 1 and 5), we compared the score obtained from questionnaires with the expected value of 75 (the middle of 25 and 125). According to Table 3, the mean of instructors' attitude ( $M=63.10)$ was less than 75. The statistical significance of the difference was tested by the one-sample t- test as presented in Table 5. The necessary condition of normality was satisfied as indicated in Table 4.

Table 5. The one-sample t-test for the Instructors' attitude toward their ESP course

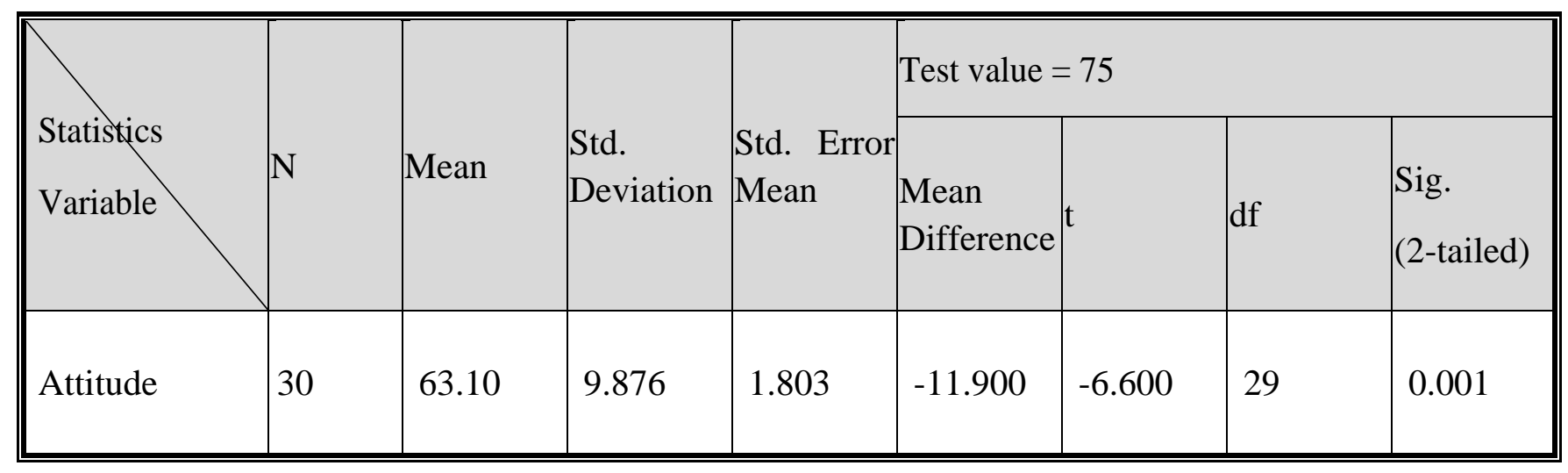

As shown in Table 5, the t-test was significant at the level of $0.01 \quad(t=6.600, d f=29$, $\mathrm{p}=0.001<0.01$ ). Thus, the difference between the instructors' attitude mean and the expected value (75) was significant. In other words, the attitude of instructors toward the ESP course was significantly lower than the average.

\subsection{Analysis of Instructors Responses to Open-ended Questions}

\subsubsection{Instructors' Responses Regarding Iinstructors' Expertise}

According to most instructors of both computer department and English language department, what seems to be important was not the instructors degree and expertise but the principle of teaching English accompanied by subject-matter expertise as well as a good command of English was the gist of the capability for teaching ESP. In other words, they suggested that any of computer instructors who had taken the IELTS or TOFLE exam with acceptable grade 
or English instructors who were familiar with the computer expertise and subject-matter texts could teach this course effectively.

\subsubsection{Instructors' Responses Regarding Strengths of ESP Classes}

Most of the university instructors believed that unfortunately there were no effective strengths in their ESP classes or perhaps the only strength of ESP classes was that students made familiar with their field of study in English including specific words and terminologies. Based on their views, universities had a serious crisis in connection with this area of language.

\subsubsection{Instructors' Responses Regarding Weaknesses of ESP Classes}

All of the instructors have replied to this question. It is worth considering their viewpoints which were absolutely informative and warning. According to instructors' responses, these weaknesses were highlighted:

Primarily, lack of class-hours, motivation, interest and the large number of students were regarded as a major problem. Next, The English background of the students had not initially been developed. As Maleki (2006) demonstrated that low English language proficiency of Iranian EFL students hindered their academic progress. Indeed, they claimed that there was no convenient curriculum and the practical skills were not boosted. Following that, the most common complaint was about General English (GE). They highlighted that GE has neither met the students' primary needs nor prepared them for, the later stage, ESP courses.

Particularly, one of the instructors, who taught in Shiraz University, reported that unfortunately, in Shiraz University all engineering students with different branches attend an ESP class which is definitely far from the pedagogical standards. In fact, ESP courses were offered in three different sciences (engineering, science, humanities).As an example, all engineering students from different disciplines had to attend an ESP class and study a textbook containing several different passages and terminologies which did not have much to do with their field of study. Another main weakness was that ESP books, for which translations were available in the market, introduced by some instructors were not effective sources. On the other hand, translating the ESP texts into Persian language was a terrible way of teaching an ESP course but most of students who had weak background of English preferred this way of teaching.

\subsubsection{Instructors' Suggestions for Improvement of ESP Program}

Some practical suggestions made by instructors were as follows:

1. Increasing the class-hours and reducing the number of students were primarily the two points that have been widely shared.

2. Most of the instructors suggested that "teaching this course in English, applying updated sources as well as teaching aids, employing a multimedia approach, using English Lab, providing conversational workshops to engage the students with oral production, increasing the expertise knowledge of instructors, motivating the students, assigning a different task to 
all of the students and avoiding translating the texts in Persian" could facilitate the teaching and learning.

3. They strongly recommended that more hours should be allocated for ESP classes and it would become more fruitful if it were extended in two levels, i.e., ESP 1 and 2.

4. One of the experienced instructors made a practical suggestions in three steps: the first step, both GE and ESP classes should be categorized into a few levels; the second one, students should be given a placement test as soon as they enter universities to determine which level, with regard to their language ability, is convenient for them; the third one, achievement test should be given during the semester. The aforementioned suggestion can, to great extent, raise the efficiency of learning and teaching in a way that students receive the instruction to the extent they actually need.

\subsection{Discussion}

From the instructors perspectives, it was inferred that the current situation of teaching-learning ESP in most Iranian universities is not satisfactory. They criticized the unworthy ESP course books, lack of a practical curriculum, lack of attention toward (GE). They all emphasized that general English should be modified, otherwise it would make the instruction more difficult. Moreover, translating a text has been evaluated as a useless old method.

The aforementioned perspectives of instructors are compatible with the findings of the research conducted by Mirza Suzani, Yarmohammadi, and Yamini,(2011).

The results of this survey indicated the warning factors which need to be eradicated in order to take full advantages toward such courses. Some inhibiting factors as cited in Mirza Suzani, Yarmohammadi, and Yamini, (2011, p.189-190) are as follows:

1- When the instructor lacks sufficient familiarity with or knowledge of fundamental principles or strategies of EFL teaching.

2- When few authentic, appropriate, and up-to-date materials are used or recommended to the learners to work on.

3- If the main goals and objectives of teaching ESP are completely unknown to the students, i.e. if the learners are not familiar with the philosophy behind ESP course and language learning strategies (LLS) in ESP classroom.

4- If there is no set of comprehensive and definite lesson plan, stratagem and objectives for teaching the materials. In other words, when learners cannot achieve fruitful results because of not knowing exactly what to read, how to read and why to read.

5- If the students are extremely exhausted and feel fatigue because of overwork and extra-curricular activities in their educational institutions, or because they have little time for physical and psychological relaxation.

6- In all-round comprehensive education program all kinds of physical, psychological and 
affective filters that may lessen or weaken the educators' motivation and attitude toward learning should be seriously inhibited.

\section{Conclusion}

The results revealed that instructors' attitudes are below the expected level toward their ESP course. To sum up, we came to the conclusion that the current situation of ESP course in the field of computer engineering was not satisfactory for ESP instructors. The instructors believed that the current situation of teaching ESP was completely ineffective. Indeed, the teaching-learning of ESP is not perceived well in Iranian universities. Therefore, it is recommended that the current situation be rectified based on needs analysis which serves authentic teaching, practical texts, and serious educational rules. Of course, in recent years some academicians have emphasized on revising of this program which caused the authorities to take satisfactory steps toward improvement of this program which worth appreciation. Still, there exist some shortages and problems which fundamentally need to be paid much more attention. The researchers have made some constructive suggestions. It is hoped that these recommendations will be taken into consideration.

\subsection{Researchers'Suggestions for Improvement of ESP Course}

The researchers evaluated the students' attitudes toward their ESP course including the content of their textbooks, the method of teaching, ESP testing, the instructors' feature, strengths and weaknesses of their ESP classes and their suggestions for betterment of this course. The researchers have made some suggestions based on the findings for program organizers and curriculum planers to take constructive steps for improvement of ESP program.

1. As it was reported that all students have already studied ESP contents in Persian (their mother tongue) and considering the fact that ESP goals are aimed at training professional experts by developing the students' English knowledge through teaching the words, terminologies, and technical texts relevant to their field of study, it is suggested that this course be taught by English instructors who have enough familiarity with subject-matter and sometimes with reference to computer instructors. Because students are exposed to authentic contexts by which they can be motivated and interested to learn English eagerly.

2. The instructors should function as a motivator because by motivation students learn easily. In other words, learning would be facilitated. One way is that instructors should speak English. Moreover, they can allocate certain marks for students' participations in class activities and their homework or encouraged them to choose one topic in which they are interested, do research on it and then present in front of a class and finally the instructors give them a bonus mark which, to some extent, functions as a good motivator.

3. It is recommended that instructors should encourage students to read articles in original sources, assign them to give lecture to live audiences and apply practical textbooks which are compatible with students' needs.

4. A joyful atmosphere should be created for students in order to get rid of tiredness and feel 
comfortable. This feature has a significant role because in such cases students are willing to participate in class activities.

5. It is recommended that ESP classes take full advantage of English Laboratories, at least two sessions a semester, by which students can improve their oral skills more effectively.

6. It was reported that general complaints were about the English background of the students. To this end, it is recommended that, first, both GE and ESP classes should be categorized into three levels as elementary, intermediate and advanced. Second, the English department should administer a formal test from all freshmen to measure their competence in English and determine which level they should be placed. As a result, they can be given required instruction as much as needed in a way that those who are placed in elementary levels have to pass the three intended levels for this course.

7. The instructions, whether in quantity or quality aspects, should be standardized. For example, it seems that the period of instruction for one credit of a course in Iranian universities has been considered to be sixteen hours in a Semester. Most specifically, it is expected that all of the sixteen hours should be held completely, even if those sessions coincide with holidays or suddenly become off due to air pollutions or the weather condition such as snow, flood, rain, hotness, ...etc. the make- up sessions should be held as it has many years been administered in some institutes, Iran Language Institute (ILI) is a shining example, which can raise the quality of teaching in such cases. Furthermore, curriculum planners should design a good lesson plan and ask the instructors to use it in process of teaching. It can bring the pedagogical standards to academic institutions.

8. In order that instructors accomplish their task, it is recommended that the class size should be reduced.

9. In order that students take full advantage of ESP classes more effectively, it is suggested that documentary films and special texts in newspaper be discussed in classrooms.

10. It is suggested to apply ESP books written jointly by two university instructors from two different disciplines ( both English and computer instructors ), such books have been written recently and available in the market, to enhance the output of ESP classes.

11. It is highly recommended to use computer assisted language learning (CALL) in order to train autonomous learners. As Benson (2001) believed that the recent attentions have been drawn toward the influential role of technology in developing of learner autonomy.

12. It is recommended that instructors adapt themselves to new teaching-learning situation. As Robinson (1991) suggested that key quality needed by the ESP teachers is flexibility.

\subsection{Implications, Limitations and Issues for further studies}

It should be noted that evaluating attitudes is particularly helpful to gain good and helpful insight into the nature of materials. Therefore, it is worth mentioning that evaluating instructors' attitudes can be a good source for policy makers, course developers, program organizers and curriculum planners to improve such programs. Scaling of responses can be 
general limitation. Likert scaling is a bipolar scaling method, measuring either positive or negative response to a statement (Dawes. J, 2008, p. 61-77). Whether individual Likert items can be considered as an interval- data, or whether they should be considered, as o data is the subject of disagreement.

This study was primarily conducted to investigate the current situation of ESP course in the field of computer engineering. Surely, this research can also be conducted for other majors. A second point is that, evaluation of ESP textbooks can also be done in terms of instructors' attitudes by administrating questionnaire to them. Furthermore, research on evaluating two ESP instructors whose major is English language and subject-matter ( Non-English) as well as research on evaluation of students' achievement in terms of two ESP groups which differ in expertise of their instructors (English and subject-matter instructors) can be conducted. Finally, there may be other variables which could improve the level of students' success in learning ESP. It would be the task of the researchers to identify what these variables are, and by testing them, determine the extent to which they may affect ESP teaching and learning.

\section{References}

Ajideh, P. (2006). Schema - theory based considerations on pre-reading activities in ESP textbooks. The Asian EFL Journal, 16, 1-19.

Atai, M. R., \& Tahririan, M. (2003). Assessment of the status of ESP in the current Iranian higher educational system. LSP, Communication, Culture, and Knowledge Conference. Guilford: University of Surrey.

Benson, P. (2001).Teaching and researching autonomy in language learning. Harlow, Essex: longman.

Celce_murcia, M. (2006)Teaching English as foreign language.3rded. Boston, MA: Heinle \& Heinle. Cianflone, Eugenio. (2010) 'What Degree of Specificity for ESP Courses in EFL Contexts?'Scripta Manent. Published by SDUTS, 5 (1-2), 3-8.

Dawes, John. (2008). "Do data characteristics change according to the number of scale points used? An experiment using 5-point, 7-point and10-point scales". International Journal of Market Research, 50(1), 61-77.

Dornyei, Z. (2007). Research methods in applied linguistics. Oxford: Oxford University Press.

Dudley-Evans, T., \& St. John, M. (1998). Developments in ESP: A multi-disciplinary approach. Cambridge: Cambridge University Press.

Eslami Rasekh, Z. (2010). Teachers' voice vs. students' voice: A needs analysis approach to English for Academic Purposes (EAP) in Iran. English Language Teaching, 3(1), 3-11.

Farnia, M. (2005). The role of web resources in ESP courses. In the Proceedings of the first National ESP/EAP Conference, Tehran, Iran.

Hutchinson, T., \& Waters, A. (1987). English for specific purposes: A learning centered 
approach. Cambridge: Cambridge University Press.

Jordan, R. R. (1997). English for academic purposes: A guide and resource book for teachers. Cambridge: Cambridge University Press.

Kiany, G. R. (2005). Introduction. A published paper about the First National ESP/EAP Conference in Iran held at the Foreign Languages Department of SAMT. Retrieved September 23, 2009, from www.samt.ac.ir/asp/pdfm/983.pdf

Maleki, A. ( 2006) . A survey on the Relationship between English Language Proficiency and the Academic Achievement of Iranian EFL Students. Korea TESOL, 8(1), 49-57.

Mazdayasna, G., \& Tahririan, M. (2008). Developing a profile of the ESP needs of Iranian students: The case of students of nursing and midwifery. Journal of English for Academic Purposes, 277-289. http://dx.doi.org/10.1016/j.jeap.2008.10.008

Mirza suzani, S. (2006). Teaching ESP in the faculties of medicine and related fields: Bridging the gap between theory and practice. In G.R.Kiany \& Khayyamdar (Eds.) Proceedings of the First National ESP/EAP Conference. volume III.SAMT.

Mirza Suzani, S., Yarmohammadi, L., \& Yamini, M. (2011). A critical review of the current Situation of teaching ESP in the Iranian Higher Education Institutions. The Iranian EFL Journal, 7(6), 179-20.

Nikpour A. (2008). An analysis of specific language needs of nursing students in Fatemeh College of Nursing and Midwifery, Shiraz, Iran. Unpublished M.A Thesis. Shiraz Azad University.

Purpura, J., \& Graziano-King, J. (2003). Investigating the Foreign Language Needs of Professional School Students in International Affairs. Working Papers in TESOL \& Applied Linguistics, 4(1), 1-33.

Robinson, P. c. (1991). ESP today: A practitioner's guide. New York: Prentice Hall.

Shokouhi, H. (2005). A new discourse plan for the Iranian university ESP textbooks. In: Kiany, G. R., Khayyamdar, M. (Eds.), Proceeding of the First National ESP/EAP Conference, Vol. III. Tehran: SAMT.

Soleimani, H. (2005). EAP in Iran: drawbacks of SAMT EAP textbooks. In Kiany, G. R., Khayyamdar, M. (Eds.), Proceedings of the first national ESP/EAP Conference, volume.III. Tehran: SAMT.

Strevens, P. (1988). ESP after twenty years: A real-appraisal. In M. Ticko (ed.), ESP: State of the art (pp. 1-13). Singapore: SEAMEO Regional Language Centre. 


\section{Copyright Disclaimer}

Copyright for this article is retained by the author(s), with first publication rights granted to the journal.

This is an open-access article distributed under the terms and conditions of the Creative Commons Attribution license (http://creativecommons.org/licenses/by/3.0/). 